\title{
CHINA'S ELITE POLITICS
}

Governance and Democratization 
Series Editors: Joseph Fewsmith (Boston University)

Zheng Yongnian (East Asian Institute, National University of Singapore)

Published*

Vol. 9 Economic Reform and Cross-Strait Relations: Taiwan and China in the WTO edited by Julian Chang \& Steven M Goldstein

Vol. 10 Discontented Miracle: Growth, Conflict, and Institutional Adaptations in China edited by Dali L Yang

Vol. 11 China's Surging Economy: Adjusting for More Balanced Development edited by John Wong \& Wei Liu

Vol. 12 Tobacco Control Policy Analysis in China: Economics and Health edited by Teh-Wei Hu

Vol. 13 China's Science and Technology Sector and the Forces of Globalisation edited by Elspeth Thomson \& Jon Sigurdson

Vol. 14 Migration and Social Protection in China edited by Ingrid Nielsen \& Russell Smyth

Vol. 15 China's Reforms at 30: Challenges and Prospects edited by Dali L Yang \& Litao Zhao

Vol. 16 Political Booms: Local Money and Power in Taiwan, East China, Thailand and the Philippines

by Lynn T White

Vol. 17 Politics of China's Environmental Protection: Problems and Progress by Chen Gang

Vol. 18 Oil in China: From Self-Reliance to Internationalization by Lim Tai Wei

Vol. 19 China's Elite Politics: Governance and Democratization by Bo Zhiyue

Vol. 20 China's New Social Policy: Initiatives for a Harmonious Society edited by Zhao Litao \& Lim Tin Seng

Vol. 21 Oil and Gas in China: The New Energy Superpower's Relations with Its Region by Lim Tai Wei

*To view the complete list of the published volumes in the series, please visit: http://www.worldscibooks.com/series/scc_series.shtml 


\title{
Series on Contemporary China - Vol. 19 \\ CHINA'S ELITE POLITICS \\ Governance and Democratization
}

\author{
Bo Zhiyue \\ East Asian Institute,
University of Singapore, Singapore \\ East Asian Institute,
National University of Singapore, Singapore
}

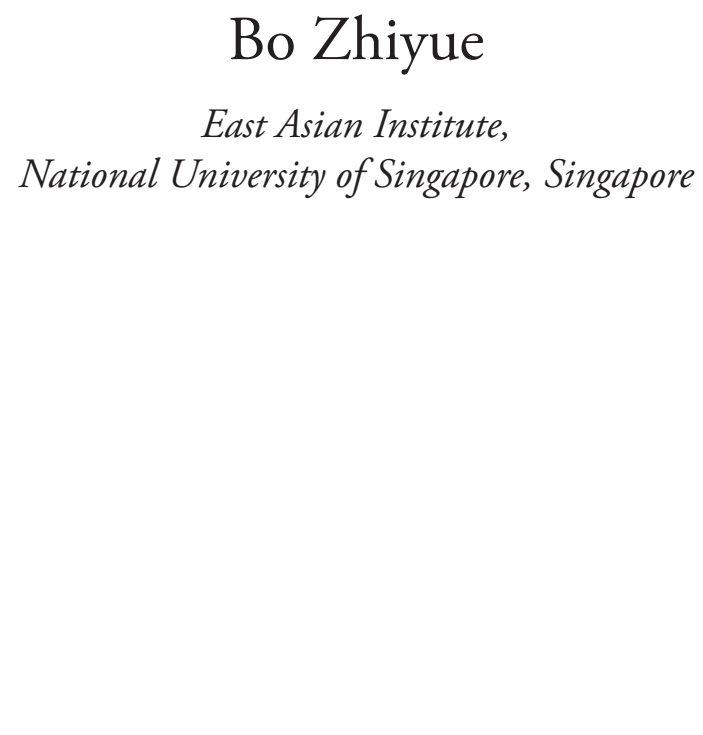


Published by

World Scientific Publishing Co. Pte. Ltd.

5 Toh Tuck Link, Singapore 596224

USA office: 27 Warren Street, Suite 401-402, Hackensack, NJ 07601

UK office: 57 Shelton Street, Covent Garden, London WC2H 9HE

\section{British Library Cataloguing-in-Publication Data}

A catalogue record for this book is available from the British Library.

\section{Series on Contemporary China - Vol. 19 CHINA'S ELITE POLITICS \\ Governance and Democratization}

Copyright (C) 2010 by World Scientific Publishing Co. Pte. Ltd.

All rights reserved. This book, or parts thereof, may not be reproduced in any form or by any means, electronic or mechanical, including photocopying, recording or any information storage and retrieval system now known or to be invented, without written permission from the Publisher.

For photocopying of material in this volume, please pay a copying fee through the Copyright Clearance Center, Inc., 222 Rosewood Drive, Danvers, MA 01923, USA. In this case permission to photocopy is not required from the publisher.

ISBN-13 978-981-283-672-4

ISBN-10 981-283-672-1

Typeset by Stallion Press

Email: enquiries@stallionpress.com

Printed in Singapore. 
This page intentionally left blank 


\section{Preface}

Dr. Bo has long been a major contributor to the literature on China's elites. This is the third of a trilogy. The first book, Chinese Provincial Leaders: Economic Performance and Political Mobility since 1949, came out in 2002. The second, China's Elite Politics: Political Transition and Power Balancing, dealt with the subject as it stood at the Sixteenth Party Congress, held in 2002. And this volume, the third, analyzes the Chinese ruling elite as it emerged at the Seventeenth Party Congress, which met in 2007.

In addition, Dr. Bo undertook a second, major task in this book, namely to assess the leadership's capacity to govern. He did this by examining how it handled four major crises and challenges that arose in 2008: the paralyzing snow storm early in the year, the Tibetan riots in March, the devastating earthquake of May, and the August Olympics. This is an unusual and creative approach to the analysis of elite politics.

The elite portion of the book can be read on two levels. First, the elite chapters constitute a very important work of reference for readers interested in the current Chinese rulers. Here, Dr. Bo has performed a major service to the profession. Prodigious research enabled him to produce a series of tables that contain an astonishing amount of information about the people who lead the most important political institutions of the country. If the reader wants to know how many Central Committee members hold $\mathrm{PhD}$ degrees, s/he can find the answer: 52, up from 12 on the Sixteenth Central Committee. 
Readers interested in the representation of non-Han minorities, of women, in age distributions, educational levels, or study abroad experiences, can find an appropriate table.

The second, even more important level, is analytical. Dr. Bo brings to bear his own methodology to answer important political questions. A chapter is devoted to the shifting factional balance among the leaders, which, for instance, shows the numerical decline of the "Shanghai Gang" and the rise of the Youth League group around Party General Secretary and President Hu Jintao. Another chapter analyzes representation on the Central Committee of various Party and government institutions. Dr. Bo constructs a "representation index" for provinces, central institutions, and the military. He looks at the shifting balance of power between those Central Committee members who serve in provinces and those at the center. The fundamental finding is that Chinese political elite is becoming more and more institutionalized in terms of regularity of career patterns and of acceptance of key rules of the game.

The four "crisis" chapters show China's leaders in action. Dr. Bo's meticulously gathered data enables him to shed light on regime performance. The chapter on Tibet is an impressive effort to defend the Chinese record. Dr. Bo marshals a great deal of historical and contemporary data to make his case. Undoubtedly, others in the international academic community may take issue with his findings. In the case of the great snowstorm, he shows how leaders were more effective than others in taking remedial action. In contrast, the mobilization of national and international resources and personnel that followed up on the May earthquake was truly impressive and very much in contrast to the leadership's performance during the even deadlier Tangshan earthquake in 1976, a measure of the distance that the Chinese ruling elite has come. And of course, the Olympics demonstrated to the world that China has truly arrived on the world stage. These chapters augur well for the capacity of China's leaders to handle the current global economic crisis.

Thomas P. Bernstein Professor Emeritus Columbia University 


\section{Acknowledgments}

A sequel to China's Elite Politics: Political Transition and Power Balancing (World Scientific, 2007), this book has sprung out of my concerns for China's future political development. Democracy, as Yu Keping puts it, is a good thing. But democratizing countries have yet to demonstrate their superior performance in governance. Popularly elected political leaders have increasingly suffered from a lame duck phenomenon. Once electoral euphoria subsides, these leaders' approval ratings plummet. Instead of trusting these elected officials to do what is right for the country, citizens, often mobilized by opposition leaders, began to ask soon after the inauguration, "Who is next?" Should China follow suit anyway because democracy somehow is good for China in the long run? Or should China focus on governance instead of democratizing? Or should China conceive a new model of democracy that is appropriate for China's social and economic conditions? The following pages will attempt to provide a tentative answer.

I would like to thank Professor Wang Gungwu, Professor Yang Dali, and Professor John Wong of the East Asian Institute (EAI), the National University of Singapore, for having accepted me as a fulltime staff in this internationally-esteemed institution of China studies. Over the past four years, I have grown fond of the EAI and Singapore and would appreciate an opportunity for intellectual development in this stimulating scholarly environment. My thanks also go to 
Professor Zheng Yongnian and other colleagues (in particular Professors Thomas P. Bernstein and Dorothy J. Solinger) at EAI for their continuous support and Ms. Sandhya Venkatesh of World Scientific for her persistent assistance throughout the entire process of producing these two books. My parents, Bo Tingxiang and Zhang Shaoqing, have always been there for me in the past decades, and I am truly grateful to my wife, Yan Dong, for her love and support. I dedicate this book to our son, Lin Bo, for being so wonderful.

I acknowledge with thankfulness the publishers for permitting me to reprint the following articles with revisions:

Chapter 3, "Institutional Representation", was originally published as "The CCP's Seventeenth Central Committee: Institutional Representation" in Issues \& Studies 41, no. 1 (September 2008): 1-41. Chapter 4, "Factional Balance", was originally published as "Balance of Factional Power in China: The Seventeenth Central Committee of the Chinese Communist Party" in East Asia 25, no. 4 (December 2008): 333-364. 


\section{Contents}

Preface vii

Acknowledgments ix

List of Tables xiii

List of Figures xvii

List of Maps $\quad$ xix

Introduction: China's Political Elites and Their Challenges $\quad 1$

Part I: Who Governs: China's Political Elites 17

1. Top Leadership 19

2. Central Committee 53

3. Institutional Representation 91

4. Factional Balance 131

Part II: How to Govern: Challenges 175

5. Snowstorms in the South 177

6. The Tibet Issue 199

7. Sichuan Earthquake 271

8. Beijing Olympic Games 323

Conclusion: China's Prospects for Democratization 383

$\begin{array}{ll}\text { Index } & 393\end{array}$ 
This page intentionally left blank 


\section{List of Tables}

Table 1.1 The Seventeenth Politburo Standing

Committee (October 2007)

Table 1.2 Average Age of Politburo Standing

Committee Members

Table 1.3 The Seventeenth Politburo (Excluding Standing Members) (October 2007)

Table 1.4 Average Age of Politburo Members (1982-2007)

Table 1.5 The Seventeenth Secretariat (October 2007)

Table 1.6 The Seventeenth Central Military Commission

(October 2007)

Table 1.7 Average Age of China's Top Leadership

(October 2007)

Table 2.1 Educational Levels of the Seventeenth Central Committee (2007)

Table 2.2 PhD Holders of the Seventeenth Central

Committee Members

Table 2.3 Overseas Studies Experience Among Central

Committee Members

Table 2.4 Countries of Foreign Learning Experience

Table 2.5 Academicians in the Seventeenth Central 
Table 2.6 Average Ages of Central Committee Members (1997-2007)

Table 2.7 Work Experience of Central Committee Members

Table 2.8 Party Standing of Central Committee Members

Table 2.9 Distribution of Home Provinces of Central 75 Committee Members

Table 2.10 Females in the Central Committee 78

Table 2.11 Distribution of Nationalities among 80 Central Committee Members

Table 2.12 Central Committee Members with Provincial Experience

Table 3.1 The Seventeenth Central Committee by Institution

Table 3.2 Elite Provincial Units in China (1969-2007)

Table 3.3 Provincial Central Committee Representation (1969-2007)

Table 3.4 Central Party-Institution Central Committee Representation (October 2007)

Table 3.5 Central Government Central Committee Representation (October 2007)

Table 3.6 Other Central Institution Central Committee Representation (October 2007)

Table 3.7 Military Central Committee Representation

(October 2007)

Table 3.8 Corporate Central Committee Representation (October 2007)

Table 4.1 Members of the Shanghai Gang in the

Seventeenth Central Committee

(October 2007)

Table 4.2 Qinghua Graduates in the Seventeenth

Central Committee (October 2007)

Table 4.3 Princelings in the Seventeenth Central

Committee (October 2007) 
Table 4.4 Group Cohesion Matrix of the Princelings

146 in the Seventeenth Central Committee (2007)

Table 4.5 CCYL Cadres in the Seventeenth Central Committee (October 2007)

Table 4.6 Provincial CCYL Cadres

158

Table 4.7 Other CCYL Cadres

Table 6.1 Tibetan Autonomous Units in the People's 202 Republic of China

Table 6.2 Tibet's Governance in the History of China

Table 6.3 Names and Tenures of Tibet's Top Leaders Since 1950

Table 6.4 Deaths Under the CCP's Rule (1949-1979)

228

Table 6.5 Funding for Tibet Projects from National

248 Endowment for Democracy (2006) 
This page intentionally left blank 


\section{List of Figures}

Figure 2.1 Population Pyramid of the Seventeenth Central Committee

Figure 3.1 Balance of Institional Power in China (October 2007)

Figure 4.1 Personal Ties of Former CCYL Secretariat Members

Figure 4.2 Personal Ties of Former Full-Time Staff Members of the CCYL

Figure 4.3 Factional Balance of the CCP Central Committees $(2002,2007)$

Figure 4.4 Group Cohesion Index of Factional Groups in China $(2002,2007)$

Figure 6.1 Ethnic Distributions of Tibetan and Han Populations in Tibet

Figure 6.2 Han Population in Tibet (1964-2005)

Figure 6.3 Central Subsidies to Tibet (1952-2006) 
This page intentionally left blank 


\section{List of Maps}

Map 6.1 Tibet Autonomous Region

200

Map 6.2 The Dalai Lama's Tibet

201 